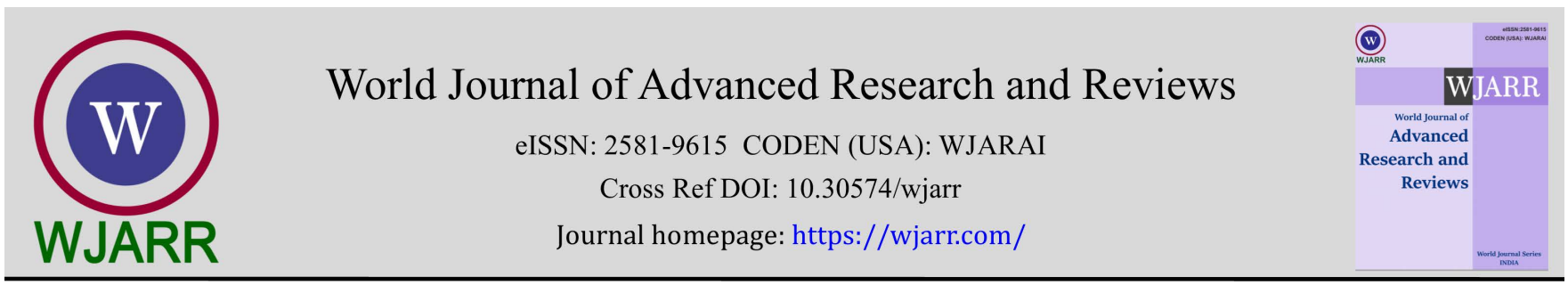

(RESEARCH ARTICLE)

\title{
Spatial distribution of outdoor thermal human comfort in the UAE
}

\author{
Mohammed Kishta, S.M. Robaa, M.M. Abdel Wahab and Zaher Al Abadla* \\ Astronomy, Space Sciences and Meteorology Department, Faculty of Science, Cairo University, P.O. 12613 Giza Egypt.
}

World Journal of Advanced Research and Reviews, 2022, 13(02), 043-049

Publication history: Received on 25 December 2021; revised on 30 January 2022; accepted on 01 February 2022

Article DOI: https://doi.org/10.30574/wjarr.2022.13.2.0104

\begin{abstract}
This study analyzed the thermal comfort in arid-desert climate of the United Arab Emirates based on the Discomfort Index (DI) and Universal Thermal Climate Index (UTCI) method. For this purpose, the average monthly meteorological data including temperature, wind speed and relative humidity were obtained from three stations (Abu Dhabi, Dubai and Al Ain) during (1980-2018) period. The result indicated that the highest value of DI and UTCI obtained in Abu Dhabi during August, with $37.7^{\circ} \mathrm{C}$ and $59.2^{\circ} \mathrm{C}$ respectively. UTCI values indicating strong heat stress found during period from April to November months. Discomfortable is very strong and dangerous in April, while State of medical emergency found from May to October. Al Ain has a lower number of comfortable months of both indexes, for which the winter months are comfortable in the three areas. The United Arab Emirates is one of the first countries concerned with climate change and trying to limit its future impacts. Therefore, created a ministry for this purpose which is, the Ministry of Climate Change and Environment.
\end{abstract}

Keywords: Environmental Evaluation; Heat Stress; DI; UTCI; UAE

\section{Introduction}

Abu Dhabi and Dubai are a coastal city with higher levels of humidity compared to AL Ain city. Al Ain is located in the border with Oman and the air is relatively dry during summer and winter [1]. Al Ain's climate is prevailed by high air temperatures and intensity solar radiation during the year. During most of the year, the rising observed temperatures exceed the thermal comfort zone range. The National Bureau of Statistics recorded the maximum average annual temperature to be $45^{\circ} \mathrm{C}$ in August with a minimum of just $13^{\circ} \mathrm{C}$ in January [2]. The local climate in Abu Dhabi and Dubai can be characterized as hot and humid with high levels of sunlight throughout the year. During the summer months between June and September, the relative humidity level in Abu Dhabi fluctuates between 80\% and 90\%. It is clear that there is no place in the world experiencing favorable conditions and thermal comfort throughout the year, either are suffering from heat or cold stress. Nowadays, there has been much interest in the study of differentiation of bioclimatic conditions in outdoor spaces [3-5]. Various researches conducted in several countries focused on the relationship between thermal comfort and diversity of place and climate [6-10]. There are more than a hundred indices used to evaluate human thermal comfort and health hazards. The important factor determining human comfort or discomfort is the thermal component of environmental conditions and was calculated by many indices using air temperature, wind speed and relative humidity [11-19].

The main purpose of current research is study of the bioclimatic conditions of three Emirates in the United Arab Emirates using Discomfort Index (DI) and Universal Thermal Climate Index (UTCI).

\footnotetext{
${ }^{*}$ Corresponding author: Zaher Al Abadla

Astronomy, Space Sciences and Meteorology Department, Faculty of Science, Cairo University, P.0.12613 Giza Egypt. 


\section{Material and methods}

\subsection{Study Domain}

The study area located in western Asia within the latitude range between $22.0^{\circ}$ and $26.5^{\circ} \mathrm{N}$ and longitudes range between $51.0^{\circ}$ and $56.5^{\circ} \mathrm{E}$, which is a member of the Gulf Cooperation Council countries as seen in Figure 1. United Arab Emirates (UAE), union of seven Emirates along the eastern coast of the Arabian Peninsula and covers an area of approximately 83,600 square kilometers with $1,318 \mathrm{~km}$ of coastline. The largest of these Emirates, Abu Dhabi, which is a capital of the federation's. Dubai and Abu Dhabi are located along the northern coastline, while Al Ain is a city in the eastern region of the Emirate of Abu Dhabi, it is the largest inland city in the Emirates. The United Arab Emirates has an arid-desert climate with very dry and high temperature in the interior, hot and humid along the coast. The average January temperature is $16^{\circ} \mathrm{C}$, while in July the temperature averages $35^{\circ} \mathrm{C}$. Summertime the temperature can reach $45^{\circ} \mathrm{C}$ on the coast and $49^{\circ} \mathrm{C}$ or more in the inland desert.

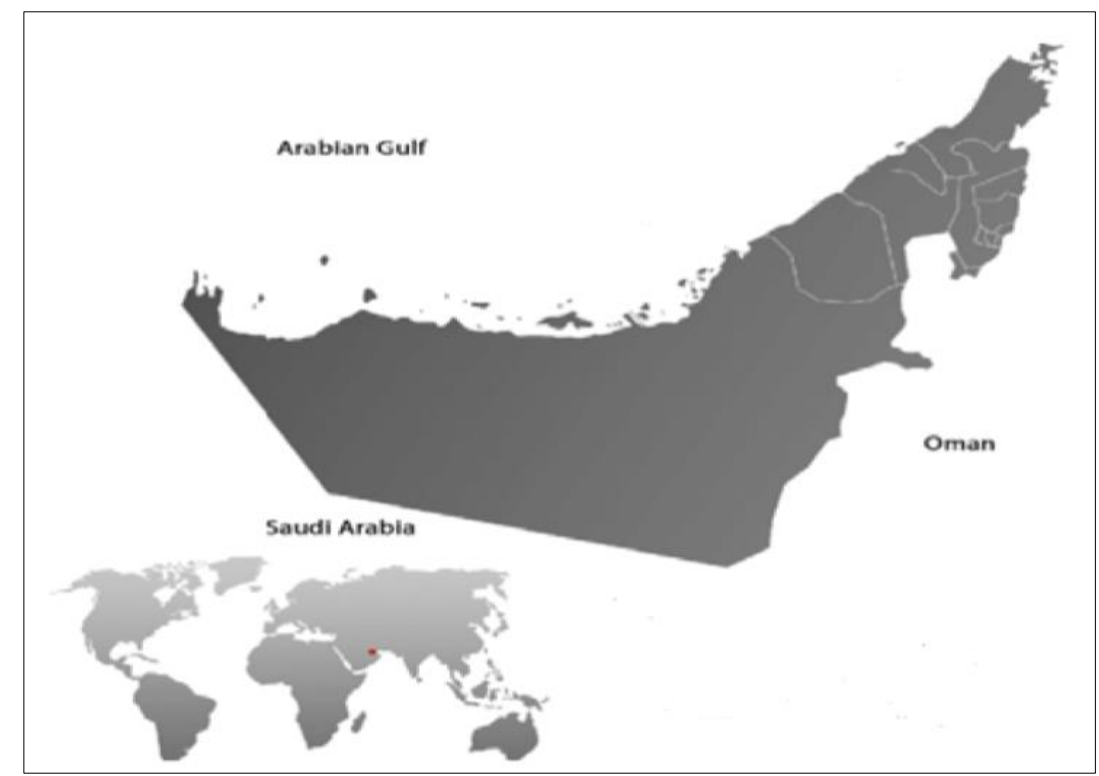

Figure 1 Location of the study area

\subsection{Methods}

Thom's Discomfort Index is calculated according to: DI = Ta - $\left.0.55-0.0055^{*} \mathrm{RH}\right)(\mathrm{Ta}-14.5)$. From the average monthly air temperature $\left(\mathrm{Ta}\right.$ in ${ }^{\circ} \mathrm{C}$ ) and the average monthly relative humidity (RH in \%). The Discomfort Index (DI) method is used to indicate the level of thermal comfort in selected study area [20].

Table 1 Classification of discomfort index values [11]

\begin{tabular}{|c|l|}
\hline DI $\left({ }^{\circ} \mathbf{C}\right)$ & Comfort Sensation \\
\hline Less than 10 & Extreme discomfort feeling \\
\hline $10-15$ & Moderate discomfort feeling \\
\hline $15-18$ & Relatively comfort \\
\hline $18-21$ & No discomfort feeling \\
\hline $21-24$ & Less than 50\% of the total population feels discomfort \\
\hline $25-27$ & More than $50 \%$ of the total population feels discomfort \\
\hline $28-29$ & Most of the population feels discomfort \\
\hline $30-32$ & The discomfort is very strong and dangerous \\
\hline More than 32 & State of medical emergency \\
\hline
\end{tabular}


Actually, UTCI shows a better picture of human thermal conditions compared to other indices. Many variables are used to calculate and estimate UTCI index which are, air temperature $\left({ }^{\circ} \mathrm{C}\right)$, relative humidity $(\%)$, wind speed $(\mathrm{m} / \mathrm{s})$ and the radiant temperature. Although UTCI index can be calculated by complex equations, in this study, the website (http://www.utci.org/) was used to assess of thermal stresses.

Table 2 Ranges UTCI indices for different grades of thermal stress [21]

\begin{tabular}{|c|l|}
\hline UTCI $\left({ }^{\circ} \mathbf{C}\right)$ & Thermal Stress \\
\hline+9 to 0 & Slight cold stress \\
\hline+9 to +26 & No thermal stress \\
\hline+26 to +32 & Moderate heat stress \\
\hline+32 to +38 & Strong heat stress \\
\hline+38 to +46 & Very strong heat stress \\
\hline above +46 & Extreme heat stress \\
\hline
\end{tabular}

In this research, the average monthly of air temperature $\left({ }^{\circ} \mathrm{C}\right)$, relative humidity $(\%)$ and wind speed $(\mathrm{m} / \mathrm{s})$ were used to calculate DI and UTCI values for UAE during the period 1980-2018.

\subsection{Observational data}

The set of meteorological parameters applied in this study consists of monthly average of air temperature, relative humidity and wind speed for the period 1980-2018 are obtained from three stations mainly located over United Arab Emirates (Abu Dhabi, Dubai and Al Ain). The observational climatic data used obtained from National Center for Environment Information (NOAA).

\section{Results and discussion}

\subsection{Universal Thermal Climate Index (UTCI)}

Different grades of no thermal stress $\left(9<\mathrm{UTCI}<26^{\circ} \mathrm{C}\right.$ ) occurred mostly from December to February in Abu Dhabi and Dubai stations, while the month of December at Al Ain station considered as moderate heat stress (Table 3). UTCI values between $38>$ UTCI $>32{ }^{\circ} \mathrm{C}$, indicating at least strong heat stress, can be found during April. The periods from June to September, extreme heat stress over the three selected area in UAE. Therefore, it can be said that at April the beginning of heat stress over UAE.

Table 3 Monthly UTCI averages (in ${ }^{\circ}$ C) at stations for the period 1980-2018

\begin{tabular}{|l|c|c|c|}
\hline Months & UTCI (Abu Dhabi) & UTCI (Dubai) & UTCI (Al Ain) \\
\hline Jan & 21.1 & 18.2 & 24.5 \\
\hline Feb & 23.8 & 20.4 & 26.8 \\
\hline Mar & 28.8 & 25.5 & 30.4 \\
\hline Apr & 37.1 & 32.9 & 35.7 \\
\hline May & 45 & 39.4 & 42.3 \\
\hline Jun & 51.5 & 45.4 & 48.3 \\
\hline Jul & 56.2 & 49.2 & 48.5 \\
\hline Aug & 59.2 & 50.4 & 51.5 \\
\hline Sep & 53.2 & 47.2 & 44.8 \\
\hline Oct & 44 & 39.8 & 38.6 \\
\hline Nov & 33.5 & 30.9 & 32.1 \\
\hline Dec & 24.7 & 24.7 & 27.1 \\
\hline
\end{tabular}


Highest UTCI values were observed at Abu Dhabi station especially during summer months $\left(59.2^{\circ} \mathrm{C}\right)$, while lowest UTCI we find at Dubai station during winter $\left(18.2^{\circ} \mathrm{C}\right)$ as shown in Figure 2

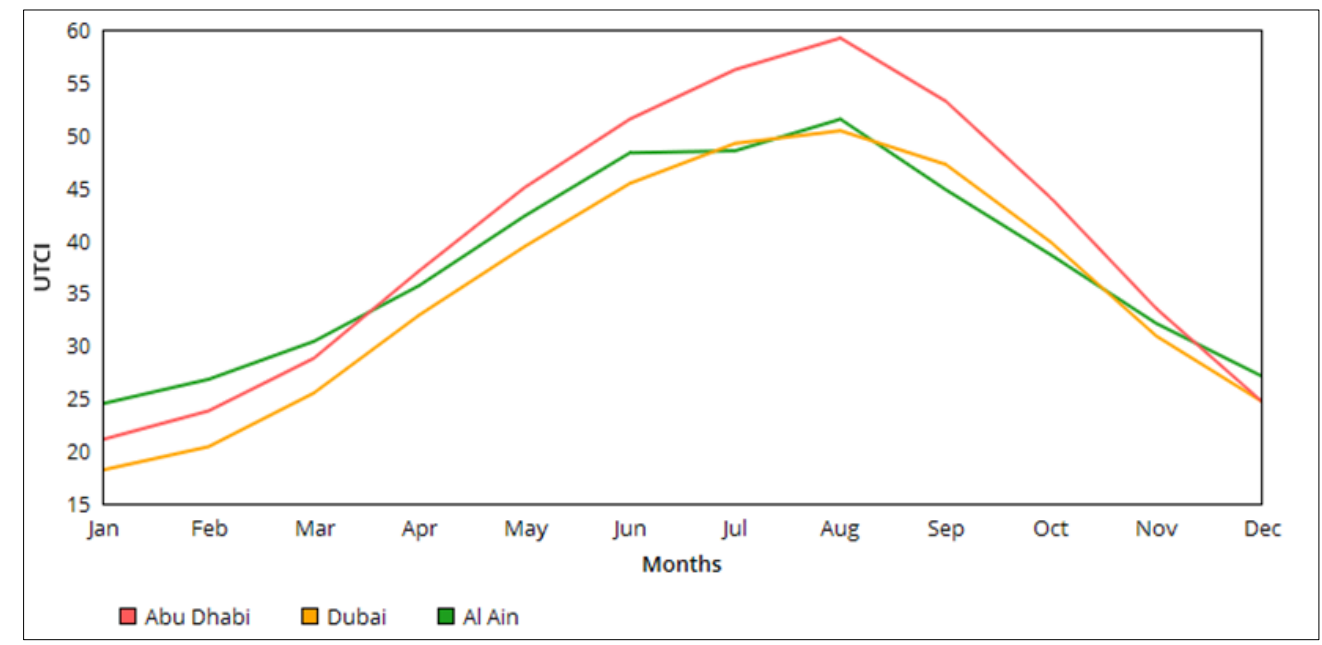

Figure 2 Average monthly UTCI $\left({ }^{\circ} \mathrm{C}\right)$ at stations for the period $1980-2019$

\subsection{Discomfort index (DI)}

Highest air temperature together with highest relative humidity produces high thermal discomfort, and vice versa. As illustrated on Table 4, in December, January and February the DI value indicated that less than $50 \%$ of the total population perceived warm discomfort nearly in the three areas. More than $50 \%$ of the total population suffered from thermal discomfort during March, while the discomfort is very strong and dangerous in April. State of medical emergency found from May to October, where the values of DI of Abu Dhabi, Dubai and Al Ain was $37.7{ }^{\circ} \mathrm{C}, 35.8{ }^{\circ} \mathrm{C}$ and $36.2{ }^{\circ} \mathrm{C}$ respectively. That's could be a dangerous situation for people, especially the elders and children.

Table 4 Monthly DI averages (in ${ }^{\circ} \mathrm{C}$ ) at stations for the period 1980-2018

\begin{tabular}{|l|c|c|c|}
\hline Months & DI (Abu Dhabi) & DI (Dubai) & DI (Al Ain) \\
\hline Jan & 23 & 22.6 & 23.2 \\
\hline Feb & 24.8 & 23.9 & 25 \\
\hline Mar & 27.5 & 26.3 & 27.4 \\
\hline Apr & 31.4 & 29.4 & 30.2 \\
\hline May & 34.3 & 32 & 32.9 \\
\hline Jun & 36.1 & 34.4 & 35.3 \\
\hline Jul & 37.1 & 35.5 & 35.3 \\
\hline Aug & 37.7 & 35.8 & 36.2 \\
\hline Sep & 36.1 & 34.8 & 34.1 \\
\hline Oct & 33.3 & 32.2 & 31.2 \\
\hline Nov & 28.8 & 28 & 27.9 \\
\hline Dec & 24.9 & 24.4 & 25 \\
\hline
\end{tabular}

In term of Discomfort Index pattern, the weather trend in UAE was alarming. The Figure 3 indicated that, in 38 years span in the three selected weather stations, showed the domination of stress and medical emergency level of discomfort index. 


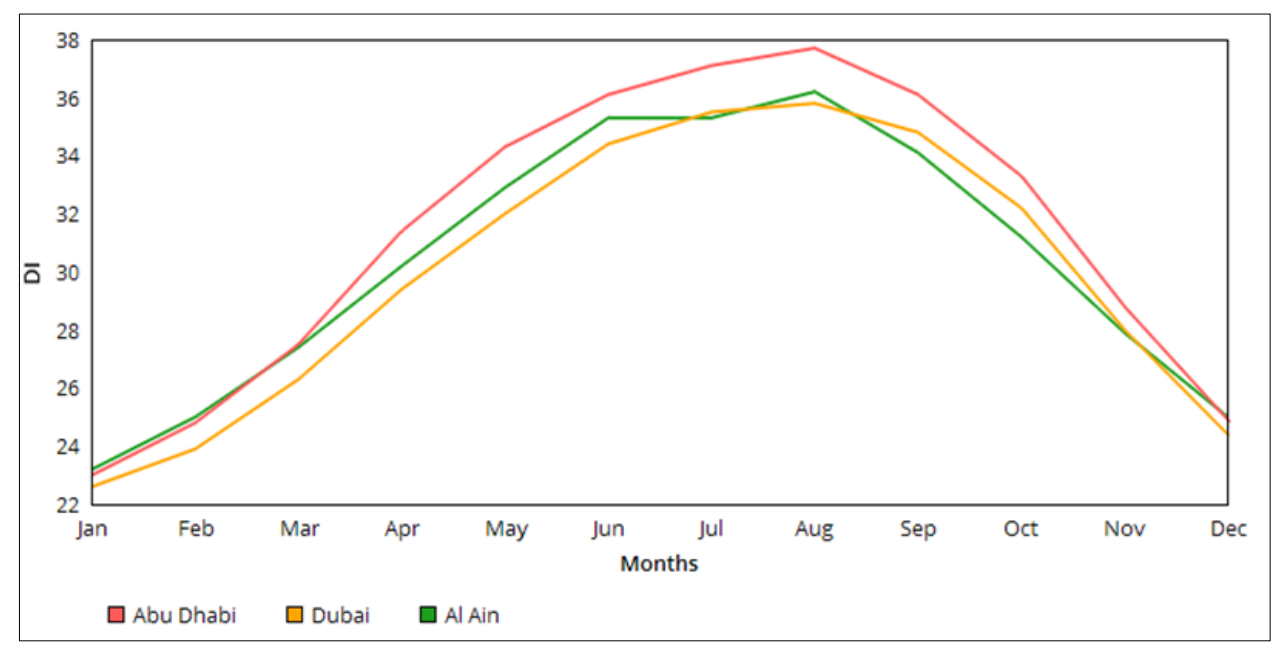

Figure 3 Average monthly DI $\left({ }^{\circ} \mathrm{C}\right)$ at stations for the period 1980-2018

The thermal human comfort indexes analyzed in this study over UAE cities are almost nearly similar representative of the thermal sensations.

Table 5 Percentage of comfortable months in three selected stations as estimated by Discomfort Index during the study period

\begin{tabular}{|l|l|c|}
\hline Stations & Comfortable Months & Annual comfortable Percentage \\
\hline Abu Dhabi & Dec, Jan and Feb & $25 \%$ \\
\hline Dubai & Dec, Jan and Feb & $25 \%$ \\
\hline Al Ain & Dec and Jan & $16 \%$ \\
\hline
\end{tabular}

As shown in Table 5 and Table 6, suggests that, Al Ain has a lower number of comfortable months of both indexes, for which the winter months are comfortable in the three areas. Dubai ranked the most comfortable among the three regions, with an annual percentage of 33\% estimated by Universal Thermal Climate Index during the study period.

Table 6 Percentage of comfortable months in three selected stations as estimated by Universal Thermal Climate Index during the study period

\begin{tabular}{|l|l|c|}
\hline Stations & Comfortable Months & Annual comfortable Percentage \\
\hline Abu Dhabi & Dec, Jan and Feb & $25 \%$ \\
\hline Dubai & Dec, Jan, Feb and Mar & $33 \%$ \\
\hline Al Ain & Jan and Feb & $16 \%$ \\
\hline
\end{tabular}

\section{Conclusion}

The UAE is located within desert-arid climate. High temperatures combined with high relative humidity increase thermal discomfort. Rising temperatures in coastal areas such as the Emirate of Abu Dhabi and the Emirate of Dubai increases the evaporation process and the air becomes saturated with water vapor, and thus the person feels uncomfortable. On the contrary, the city of Al-Ain, which does not overlook the Arabian Gulf, has a dry, hot climate.

Analysis of Universal Thermal Climate Index (UTCI) showed that there is a big difference between the highest and lowest UTCI values, the highest values restricted of Abu Dhabi station especially during summer months $\left(59.2^{\circ} \mathrm{C}\right)$, while the lowest UTCI we get at Dubai station during winter $\left(18.2^{\circ} \mathrm{C}\right)$. Annual percentage of comfortable was $16 \%$ over Al Ain. In fact, there is no feeling of thermal comfort in any of the three stations according to Discomfort Index. DI showed that 
the majority of the days of, 38 years of study period, fell into the category "more than $50 \%$ of people feel discomfort", while the summer months shows a state of medical emergency.

\section{Compliance with ethical standards}

\section{Acknowledgments}

I would like to express my special thanks of gratitude and appreciation to my Professors in Astronomy, Space Sciences and Meteorology Department at Cairo University.

\section{Disclosure of conflict of interest}

All authors of the manuscript declare that they have no conflict of interests.

\section{References}

[1] Aboulnaga MM. A roof solar chimney assisted by cooling cavity for natural ventilation in buildings in hot arid climates: An energy conservation approach in Al-Ain city. Renew. Energy. 1998; 14 : 357-363.

[2] Taleb HM. Using passive cooling strategies to improve thermal performance and reduce energy consumption of residential buildings in U. A. E. buildings. Front. Archit. Res. 2014; 3: 154-165.

[3] Evans GW. Environmental Stress. Cambridge University Press. 1982.

[4] Nikolopoulou M. Outdoor Comfort. - In: Steemers, K, Steane, MA. (eds.) Architecture and Variety: Environmental Perspectives. Spon Press, London. 2004.

[5] Geletič J, Lehnert M, Savić S, Milošević D. Modelled spatiotemporal variability of outdoor thermal comfort in local climate zones of the city of Brno, Czech Republic. - Science of the Total Environment. 2018; 624: 385-395.

[6] Nikolopoulou M, Lykoudis S. Thermal comfort in outdoor urban spaces: Analysis across different European countries. - Building and Environment. 2006; 41: 1455- 1470.

[7] Nikolopoulou M-H, Lykoudis S. Use of outdoor spaces and microclimate in a Mediterranean urban area. - Building and Environment. 2007; 42: 3691-3707.

[8] Thorsson, S., Honjo, T., Lindberg, F., Eliasson, I., Lim, E. M. Thermal comfort and outdoor activity in Japanese urban public places. - Environment and Behavior. 2007; 39: 660-684.

[9] Kántor N, Égerházi L, Unger J. Subjective estimation of thermal environment in recreational urban spaces -Part 1: Investigations in Szeged, Hungary. - International Journal of Biometeorology. 2012a; 56(6): 1075-1088.

[10] Kántor N, Unger J, Gulyás Á. Subjective estimations of thermal environment in recreationalurban spaces-Part 2: International comparison. International Journal of Biometeorology. 2012b; 56: 1089-1101.

[11] Thom EC. The discomfort index. Weather wise. 1959; 12: 57-60.

[12] Steadman RG. Indices of wind chill. J. Apple. Meteorol. 1971; 10: 674-683.

[13] Oliver JE. Climatology, Selected Applications, Winston and Sons, London. 1981; 189-191.

[14] ISO 7730: Moderate thermal environments-determination of the PVI and PPD indices andspecification of the conditions of thermal comfort. International organization of standardization, Geneva.Israel-Geography. U.S. Library of Congress. Retrieved 8 April 2008.

[15] Suping Z, Guanglin M, Yanwen W, JI L. Study of the relationships between weather conditions and the marathon race. International Journal of Biometeorology. 1992; 36(2): 63-68.

[16] Matzarakis A, Mayer H. Another kind of environmental stress: thermal stress. Newsletters no.18, 7-10. WHO collaborating center for air quality management and air pollution control. 1996.

[17] Becker S, Potchter 0, and Yaakov. Calculated and observed human Thermal sensation in an extremely hot and dry climate. Energy and building. 2003; 35: 747-756.

[18] Blazejczyk, K., Epstein, Y., Jendritzky, G., Staiger, H., Tinz, B. Comparison of UTCI to selected thermal indices. International journal of biometeorology. 2012; 56(3): 515-535. 
[19] Bröde P, Fiala D, Błażejczyk K, Holmér I, Jendritzky G, Kampmann B, Havenith G. Deriving the operational procedure for the Universal Thermal Climate Index (UTCI). International journal of biometeorology. 2012; 56(3): 481-494.

[20] Epstein Y, Moran DS. Thermal Comfort and the Heat Stress Indices. Industrial Health. 2006; 44(3): 388-398.

[21] Ketterer C, Matzarakis A. Development and application of assessment methods for thermal bioclimate conditions in Stuttgart. - ICUC8, 8th International Conference on Urban Climates, 6th-10th August, UCD, Dublin Ireland. 2012. 